\title{
RECREATIONAL PHYSICAL ACTIVITY OF INTERNATIONAL SPORTS EVENTS FANS
}

\author{
Physical activity of sports events fans
}

\author{
ANDRZEJ HADZIK ${ }^{1}$, RAJMUND TOMIKㄹ, ADAM RYSZARD SZROMEK², \\ MAREK SZCZERBOWSKI 1,3 \\ ${ }^{1}$ University of Physical Education, Faculty of Sport and Tourism Management, Katowice, Poland \\ 2 Silesian University of Technology, Department of Organization and Management, Gliwice, Poland \\ 3 "Śląski" Stadium, Chorzów, Poland
}

\author{
Mailing address: Andrzej Hadzik, Wydział Zarządzania Sportem i Turystyką, \\ Akademia Wychowania Fizycznego, Mikołowska 72a, 40-065 Katowice, Polska, \\ tel.: +4832 2075169, e-mail: Andrzej_Hadzik@wp.pl
}

\begin{abstract}
Introduction. There are currently no studies published on the relationship between participation in international sports events and physical activity of the fans. This inspired the authors to examine this subject. The aim of the study was to estimate the level of physical activity of Polish national teams' supporters of selected sports disciplines. Material and methods. The study was conducted on randomly selected group of fans during the Polish national level football, basketball and volleyball games. The study used the diagnostic survey method with a questionnaire of the authors' own design. In this report there were questions concerning physical activity modelled on the International Physical Activity Questionnaire. Results. Physical activity is usually practised by fans of basketball and football who are 19-35 years old. Fans who are not physically active are mainly the fans of volleyball and football who are 36-55 years old. A significant correlation was noted between fans' sex and the willingness to practice sport $(p=0.016) .58 \%$ of women and $72 \%$ of men declared that they practice some recreational physical activities. The most active were the basketball fans; the least active were the volleyball fans. The greatest diversity in terms of physical activity depending on participants' sex was revealed among the fans at international football games. Additionally, a significant correlation was noted between fans' age and their willingness to practice sports in their free time $(\mathrm{p}<0.001)$. Conclusions. The majority of fans at international sports events are physically active. In the research groups analysed the weekly volume of physical activity varied significantly. The basketball fans spent the greatest amount of time on physical activity and the volleyball fans the lowest. The average frequency of physical activity was the same in all groups.
\end{abstract}

Key words: sports tourism, recreational physical activity, international sports events fans

\section{Introduction}

Travelling to sports events began in ancient times. A good example can be popular destinations connected with the games at Olympia. If, however, the ancient sports events travellers came from Greek cities, now at the international sports events one can meet fans from all over the world. Klisiński [1] divides sports tourism into: (i) physically active tourism; (ii) tourism based on sports events. Krawczyk [2] is of the same opinion; that sports tourism has its base in physical recreation and dynamic development of professional sport, which means organizing a growing number of high-level sports events in Poland.

One of the concepts of sports tourism is presented by Zauhar [3], who included this type of activity into the new tourist phenomena. The author divides sports tourism into five different catagories, namely:

- sport tourism attractions, such as parks, mountains, environmental qualities, museums and sports-related objects;

- sport tourism resorts, where sports and recreational activity is a key component of the visitors' health activities;

- sport tourism cruises, during which the services associated with physical activity are an essential component of the product offered;

- $\quad$ sport tourism tours, where tourists are interested in practising physical activities and recreation;

- $\quad$ sport events tourism, during which tourists are sport fans.

Some researchers also include sport adventure tourism within sport tourism, which is connected with physical activity such as climbing, extreme skiing or scuba diving [4].

One of the most frequently quoted concepts of sport tourism are from Hall [4], Standeven and Deknop [5], which are based on the category of passive - active participations in this type of travel. Hall [4] divides sport tourism into two main categories:

- travel aimed at undertaking physical activity; called active sport tourism,

- travel by fans who watch sports events passively; called sport events tourism.

Standeven and Deknop [5] in turn define sport tourism as all forms of active and passive involvement in sports activity away from home and work, which may or may not be organized in character; their motivations may or may not be connected with economic or non-economic reasons. 
Whether the participation in sport and tourism is passive or active and whether the participants are more involved in sport or tourism depends mainly on primary and secondary human needs [6]. Robinson and Gammon [7] grouped the respondents as participants of so-called sport-tourism depending on the emphasis on sport or tourism. Some of them will be more motivated by sport, others by tourism. However, all of them are influenced by both typically sport and strictly tourist elements.

According to the authors, we can divide active, qualified and health tourism, all of which are becoming increasingly popular. That is why the concept of sport-tourism should be limited to travelling to sports events and, in particular, the major international sports events such as the Olympic Games, World and European Championships in popular sport disciplines. Sport-tourism means taking the role of a fan or participating in amateur competitions. Professional athletes and their staff (coaches, physiotherapists, technical service) travel to sports events for professional reasons and this excludes them from the group of people who travel with tourist aims.

Therefore the largest group of participants in sport-tourism are fans who travel to away out of their place of residence to places where sports events are held. The fans' participation in international sports events is the subject of a growing number of studies [8]. Sport-tourism studies are generally connected with the assessment of the effect of sports events on the economy and promotion of the destination areas, the organization and management of big sports events and the characteristics of tourists/supporters, mainly in terms of sociology and psychology. In Poland, the issue of sport-tourism is a new area of ?research in physical culture [9].

In addition to economical and sociological issues there is no study on physical culture dealing with the analysis of the physical activity level of participants of international sports events and the impact of these events on encouraging fans to undertake physical activities in their free time. In recent years researches on the determinants of physical activity are, conversely, widespread. Physical activity is one of the most important lifestyle factors, its impact on health being defined as a direct and fundamental element of good health. The World Health Organization (WHO) defines physical activity as: "every activity requiring energy expenditure involving the skeletal muscles of the body." It is also assumed that physical activity is any movement of the body associated with muscle contraction, which increases energy expenditure above that of a resting state $[10,11]$. It can be associated with exercises during professional work, housework, walking as well as recreational behaviours and sports activities conducted during the free time [12]. Numerous studies $[13,14,15,16,17,18,19,20,21,22]$ show that the level of physical activity in most modern societies is far below the recommendations of the World Health Organization (WHO), according to which the health benefits come from at least 10 minutes of daily exercises with an intensity of $80 \% \mathrm{HR}$ max or $\mathrm{VO}_{2}$ max; the health and physical activity should exceed 3.5 hours per week.

This prompted the authors to undertake research into possible connections between participation in international sports events and physical activities of the fans. The aim of the study presented in this report was to identify the level of physical activity of the fans of selected Polish national teams.

Before the study, the following research questions were formulated:

1. Who amongst the fans are physically active? Do their gender or supported sports disciplines differentiate their physical activity?

2. What is the volume and frequency of physical activity of the fans depending on their participation in various sports events?

3. What are the general characteristics of the various groups of supporters i.e. football, volleyball and basketball fans?

\section{Material and methods}

The research was conducted in 2009 on randomly selected groups of fans during two Polish national football team games, one of which was during the final stages of European Championships in basketball (men) EuroBasket 2009 and the other during European Championships in volleyball (women). For the purposes of this study, 900 seats were randomly selected in the "Spodek" hall in Katowice and the "Śląski" Stadium in Chorzów. $429(47.7 \%)$ of the surveys were completed. Some respondents refused to participate in the research; some filled in their questionnaires incorrectly and some seats were not taken (Table 1). After the initial verification of the completed surveys, 58 questionnaires were rejected as they contained numerous contradictions which could affect the credibility of the research. In the end the database subjected to analysis contained data from 371 surveys (Table 1). Statistical error for the whole survey was $\pm 5 \%(\mathrm{p}=0.95)$.

Table 1. The characteristics of sports events at which the survey was carried out

\begin{tabular}{|c|c|c|c|c|c|}
\hline No & $\begin{array}{c}\text { Sports } \\
\text { discipline }\end{array}$ & $\begin{array}{c}\text { Type } \\
\text { of competition }\end{array}$ & $\begin{array}{c}\text { Place } \\
\text { of research }\end{array}$ & \begin{tabular}{|c|} 
Number of \\
respondents \\
(percentage \\
of women)
\end{tabular} & $\begin{array}{c}\text { Total } \\
\text { percentage }\end{array}$ \\
\hline 1. & Football & $\begin{array}{l}\text { Qualifying game } \\
\text { for the football } \\
\text { World Cup } \\
\text { in South Africa }\end{array}$ & $\begin{array}{l}\text { "Śląski" Stadium } \\
\text { in Chorzów }\end{array}$ & $\begin{array}{c}237 \\
(21.9 \%)\end{array}$ & 63.9 \\
\hline 2. & Basketball & $\begin{array}{l}\text { European } \\
\text { Championships } \\
\text { in Poland }\end{array}$ & $\begin{array}{c}\text { "Spodek" } \\
\text { sports hall } \\
\text { in Katowice }\end{array}$ & $\begin{array}{c}73 \\
(28.3 \%)\end{array}$ & 19.7 \\
\hline 3. & Volleyball & $\begin{array}{l}\text { European } \\
\text { Championships } \\
\text { in Poland }\end{array}$ & $\begin{array}{c}\text { "Spodek" } \\
\text { sports hall } \\
\text { in Katowice }\end{array}$ & $\begin{array}{c}61 \\
(37.3 \%)\end{array}$ & 16.4 \\
\hline \multicolumn{4}{|c|}{ Total } & $\begin{array}{c}371 \\
(23.5 \%)\end{array}$ & 100.0 \\
\hline
\end{tabular}

The vast majority of respondents were men (66.6\%), and the largest age group was people between 19-25 years of age (Table 2).

Table 2. The number of respondents according to their sex and age

\begin{tabular}{|c|c|c|c|c|c|c|c|c|}
\hline \multirow{2}{*}{ Age } & \multicolumn{2}{|c|}{ Women } & \multicolumn{2}{|c|}{ Men } & \multicolumn{2}{c|}{ No data } & \multicolumn{2}{c|}{ Total } \\
\cline { 2 - 10 } & $\mathbf{n}$ & $\%$ & $\mathbf{n}$ & $\%$ & $\mathbf{n}$ & $\%$ & $\mathbf{N}$ & $\%$ \\
\hline Up to 18 & 11 & 12.64 & 27 & 10.93 & 3 & 8.11 & 41 & 11.05 \\
\hline $19-25$ & 43 & 49.43 & 104 & 42.11 & 15 & 40.54 & 162 & 43.67 \\
\hline $26-35$ & 17 & 19.54 & 65 & 26.32 & 6 & 16.22 & 88 & 23.72 \\
\hline $36-45$ & 13 & 14.94 & 30 & 12.15 & 8 & 21.62 & 51 & 13.75 \\
\hline $46-55$ & 3 & 3.45 & 16 & 6.48 & 5 & 13.51 & 24 & 6.47 \\
\hline Over 56 & 0 & 0.00 & 5 & 2,02 & 0 & 0.00 & 5 & 1.35 \\
\hline Total & 87 & 23.45 & 247 & 66.58 & 37 & 9.97 & 371 & 100.0 \\
\hline
\end{tabular}


The study used the authors' own design method of diagnostic survey with the questionnaire. The questionnaire consisted of a short letter of intent, 10 open/close questions and the metrics. Pilot studies were carried out on a group of second-year students of sport management at the University of Physical Education in Katowice, which allowed certain questions and the letter of intent to be optimized. The questions were related to various aspects of fans' participation in the Polish national team game. In this report the questions concerning physical activity, modelled on the International Physical Activity Questionnaire (Short Last 7 Days Self-Administered Format), were used. These questions were related to sports activity and recreation in undertaken during the free time, the amount of physical activity per week and the preferred forms of physical activity.

The study consisted of a descriptive analysis in order to observe the diversity of characteristics that describe the respondents' group. The results were also identified by using statistical tests allowing the significance of differences between average values of each parameter or between the indicators of structure to be established.

The comparative analysis was performed on three (or more) independent groups of the distribution other than normal using the ANOVA Kruskal-Wallis test. In the cases of non-homogeneity of the variance of normally distributed variables, the test was performed with an independent estimation variance. The significance of differences between the examined indicators structure was examined with the chi-square test.

The results obtained were also subject to multivariate analysis. In the view of the fact that the data had the nominal characteristics nature, the correspondence analysis was used [23, 24], bringing the picture of the relationship between individual characteristics (e.g. sex, age, place of residence), behaviours and sports preferences (e.g. undertaking physical activity, the choice of sport practised, the frequency and intensity of the activity undertaken) into two dimensions, which could be presented graphically. This resulted in a graphic interpretation of taxonomic distance measures between attributes that characterize different groups of fans.

\section{Results}

\section{Declaration of physical activity vs. the sex and age of the fans}

In the research the respondents declared whether they undertook recreational and physical activity. A significant correlation was noted between the sex of fans and their willingness to practice sport $(p=0.016)$. The difference between men and women in this regard is quite clear because it is mainly men who undertake physical activity. $58 \%$ of women and $72 \%$ of men declared that they practice some form of sport. Basketball fans were the most active and the volleyball fans the least active. The greatest diversity in terms of physical activity depending on participants' sex was revealed among the fans at international football games (Tab. 3).

Table 3. Undertaking physical activity depending on the sex and sports discipline

\begin{tabular}{|l|c|c|c|c|c|c|c|c|}
\hline \multirow{2}{*}{$\begin{array}{c}\text { Declaration } \\
\text { of undertaking } \\
\text { physical activity }\end{array}$} & \multicolumn{2}{|c|}{$\begin{array}{c}\text { Volleyball } \\
\text { fans }\end{array}$} & \multicolumn{2}{c|}{$\begin{array}{c}\text { Basketball } \\
\text { fans }\end{array}$} & \multicolumn{2}{c|}{$\begin{array}{c}\text { Football } \\
\text { fans }\end{array}$} & \multicolumn{2}{c|}{ Total } \\
\cline { 2 - 9 } & M & W & M & W & M & W & M & W \\
\hline Physically active & $55.0 \%$ & $52.0 \%$ & $77.3 \%$ & $76.9 \%$ & $63.4 \%$ & $46.0 \%$ & $72 \%$ & $58 \%$ \\
\hline Physically inactive & $45.0 \%$ & $48.0 \%$ & $22.7 \%$ & $23.1 \%$ & $36.6 \%$ & $54.0 \%$ & $28 \%$ & $42 \%$ \\
\hline
\end{tabular}

M-men, W-women
It is worth noting the significant differences between the gender and the selected form of activity $(\mathrm{p}<0.001)$. Men choose football and other sports (50.57\%), while women mostly avoid football and choose other sports (60.42\%) (Tab. 4).

Table 4. The forms of physical activity undertaken by the fans

\begin{tabular}{|l|c|c|c|c|c|c|}
\hline \multirow{2}{*}{$\begin{array}{c}\text { The form of undertaken } \\
\text { physical activity }\end{array}$} & \multicolumn{2}{|c|}{$\begin{array}{c}\text { Volleyball } \\
\text { fans }\end{array}$} & \multicolumn{2}{c|}{$\begin{array}{c}\text { Basketball } \\
\text { fans }\end{array}$} & \multicolumn{2}{c|}{$\begin{array}{c}\text { Football } \\
\text { fans }\end{array}$} \\
\cline { 2 - 7 } & M & W & M & W & M & W \\
\hline The discipline they support & $26.3 \%$ & $40.0 \%$ & $15.9 \%$ & $0.0 \%$ & $23.9 \%$ & $16.7 \%$ \\
\hline $\begin{array}{l}\text { The discipline they support and } \\
\text { other forms of physical activity }\end{array}$ & $47.4 \%$ & $30.0 \%$ & $36.4 \%$ & $42.9 \%$ & $56.6 \%$ & $8.3 \%$ \\
\hline Other forms of physical activity & $26.3 \%$ & $30.0 \%$ & $47.7 \%$ & $57.1 \%$ & $19.5 \%$ & $75.0 \%$ \\
\hline
\end{tabular}

M-men, W-women

Additionally, a significant correlation was noted between the age of fans and their willingness to practice sport in their free time $(p<0.001)$. The highest activity of fans was found among people aged 19-35. Three out of four fans at this age practice some sport. However, the older age-groups' physical activity decreases and, at the age of 35-45, fewer than half still practice it. A slight improvement in the percentage of physically active fans can be seen in the next age group (44-55), but over the age of 55 it disappears completely. To sum up, up to the age of 35 the fans are interested in sport and practice it, then at the age of 35-55 their activity decreases significantly and, when they are over 55 years old, it disappears completely (Fig.1).

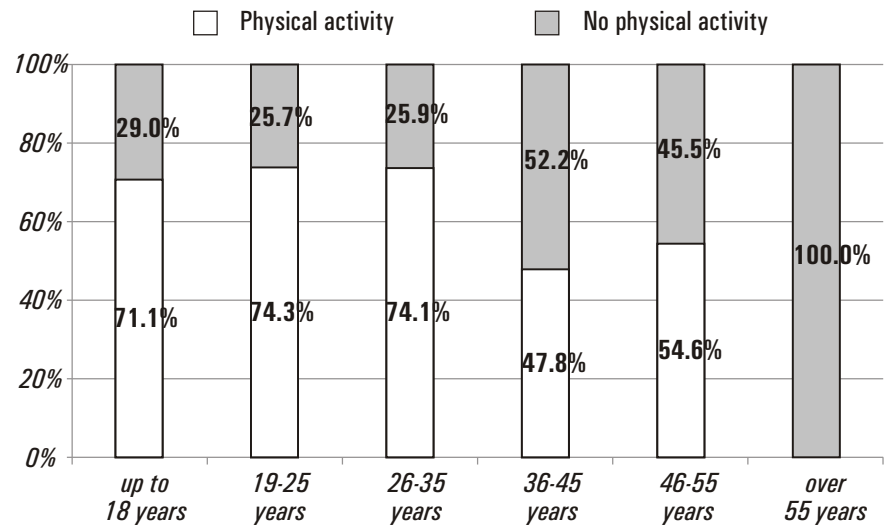

Figure 1. Physical activity vs. the age of fans

\section{The volume and frequency of physical activities of the fans}

The respondents declared significantly different levels of physical activity, depending on the sports discipline which they supported. The total number of hours per week devoted to active participation in sport averaged to 3.8 hours (all respondents). The most active were the basketball fans who devoted on average 4.6 hours to physical activity; the least active were the volleyball fans with 3.5 hours on average. Every other fan of volleyball and basketball declared a maximum of 3 hours, while the football fans declared a maximum 2 hours of physical activity per week. The most common answer was 2 hours of physical activity per week. Among the respondents, there was no differentiation of the amount of physical activity per week according to their sex (Tab. 5). 
Table 5. The amount of physical activity per week (hours)

\begin{tabular}{|l|c|c|c|c|c|c|}
\hline Measure & Overall & $\begin{array}{c}\text { Volleyball } \\
\text { fans }\end{array}$ & $\begin{array}{c}\text { Basketball } \\
\text { fans }\end{array}$ & $\begin{array}{c}\text { Fans } \\
\text { of football }\end{array}$ & Men & Women \\
\hline Average & 3.80 & 3.48 & 4.64 & 3.52 & 3.89 & 3.62 \\
\hline Std. deviat. & 3.06 & 1.96 & 3.33 & 3.09 & 3.24 & 2.51 \\
\hline Median & 2,50 & 3.00 & 3.00 & 2.00 & 2.50 & 3.00 \\
\hline Minimum & 0.50 & 2.00 & 1.00 & 0.50 & 1.00 & 0.50 \\
\hline Maximum & 17.00 & 10.00 & 16.00 & 17.00 & 17.00 & 10.00 \\
\hline $\begin{array}{l}\text { The significance } \\
\text { of differences (p) }\end{array}$ & \multicolumn{3}{|c|}{$0.0236^{*}$} & \multicolumn{3}{|c}{ NS } \\
\hline
\end{tabular}

* differences statistically significant

The frequency of sports activity undertaken was similar in each group of respondents. On average the fans engaged in physical activity three times per week. There was no significant difference in the frequency of physical activity between women and men (Tab. 6).

Table 6. The frequency of physical activity per week

\begin{tabular}{|l|c|c|c|c|c|c|}
\hline Measure & Overall & $\begin{array}{c}\text { Volleyball } \\
\text { fans }\end{array}$ & $\begin{array}{c}\text { Basketball } \\
\text { fans }\end{array}$ & $\begin{array}{c}\text { Fans } \\
\text { of football }\end{array}$ & Men & Women \\
\hline Average & 2.99 & 2.90 & 3.00 & 3.00 & 3.02 & 2.87 \\
\hline Std. deviat. & 1.45 & 1.23 & 1.19 & 1.59 & 1.49 & 1.30 \\
\hline Median & 3.00 & 3.00 & 3.00 & 3.00 & 3.00 & 3.00 \\
\hline Minimum & 1.00 & 1.00 & 1.00 & 1.00 & 1.00 & 1.00 \\
\hline Maximum & 7.00 & 5.00 & 6.00 & 7.00 & 7.00 & 6.00 \\
\hline $\begin{array}{l}\text { The significance } \\
\text { of differences }(p)\end{array}$ & & NS & \multicolumn{3}{|c}{ NS } \\
\hline
\end{tabular}

However, there was a significant correlation between the lack of physical activity and attendance of the national team games in a particular sports discipline $(p<0.001)$. The average percentage of respondents who did not undertake any physical activity was $34 \%$. Among the fans of basketball, there was only $15 \%$ of completely inactive respondents; the highest number of completely inactive respondents was found among the volleyball fans - as much as $49 \%$ (Fig. 2)

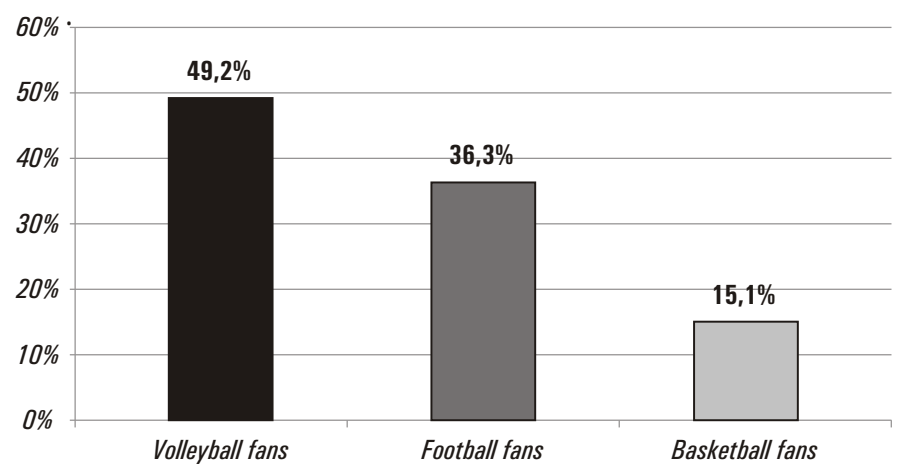

Figure 2. The percentage of fans who did not undertake any physical activity in the reported period of time
In addition to that, the percentage of respondents who pledged systematic physical activity, i.e. 4 or more times per week, amounted to $17.8 \%$ of basketball fans, $18.1 \%$ of football fans and $14.7 \%$ of volleyball fans. In the entire studied group "very high physical activity" was declared by $17.5 \%$ of respondents.

\section{General characteristics of the various groups}

of fans using the correspondence analysis

These results were also confirmed by the correspondence analysis, which simultaneously was the summary of partial conclusions. Taxonomic distances between variants of individual attributes show the similarity of answers (Fig. 3). Thus, the closer two points were positioned, the higher similarity of answers. This allowed the differences between the characteristics and behaviours of fans across particular disciplines to be noted. In the correspondence analysis the eigenvalue was 0.27 giving $9.7 \%$ of the inertia (perspective 1 ) and 0.33 giving $11.6 \%$ of the inertia (perspective 2).

The football fans were primarily men aged 19-55 and residents of large cities (over 100000 inhabitants). The volleyball fans were mainly under 18 years old of which a significant proportion were women, usually residents of smaller cities (up to 100000 inhabitants). The basketball fans were different. They were usually people from large cities (over 500000 inhabitants) but also from towns of 10000 to 50000 residents. It is interesting that the respondents from this group were most often people who practised sport; usually people up to 35 years old.

When analysing their physical activities it can be seen that, among the football fans, there were also people who like other disciplines, but the age structure of this segment is highly varied. Physical activity is usually practised by the basketball and football fans; these are people aged 19-35 years old. At the other extreme there are people who do not undertake any physical activity. This group includes the volleyball and football fans who are older than the respondents from the previous group (36-55 years). The interesting thing is also that, although the volleyball fans were mainly young people (under 18 years or 36-55 years), we can observe a different tendency in practising physical activity. Young people not only support but also practice sport, while people aged 36-55 are only supporters.

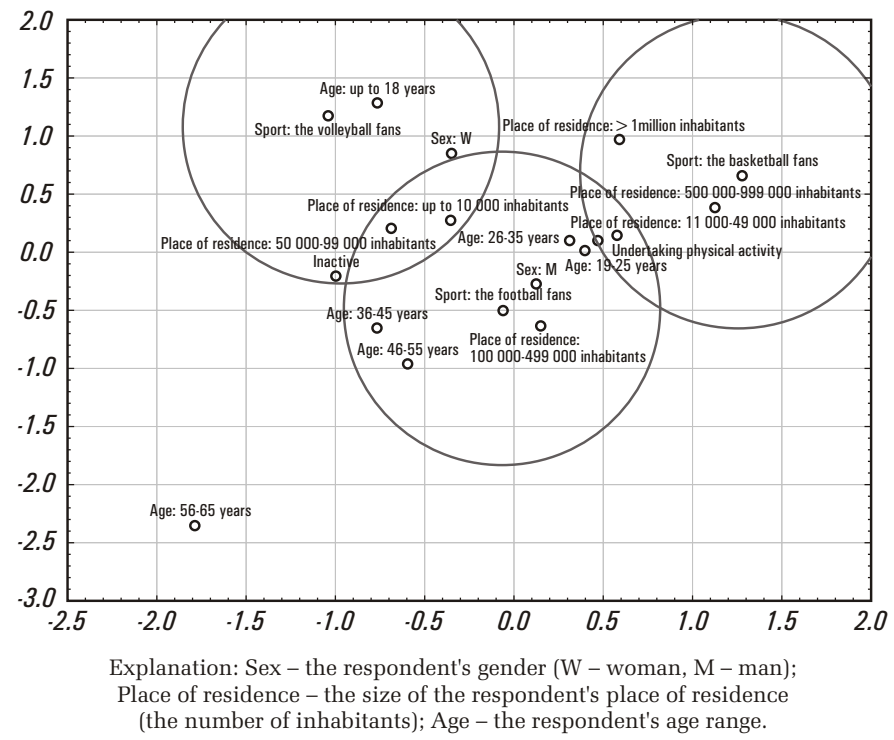

Figure 3. The characteristics of fans on the basis of the correspondence analysis 


\section{Discussion}

The research showed that supporting is connected with undertaking physical activity by $58 \%$ of women and $72 \%$ of men. The remaining respondents were physically inactive. However, this result depends on the type of discipline; the most active were the basketball fans (77\%); the least active were the volleyball fans (women: 52\%, men: 55\%). In the Eurobarometr survey "Sport and physical activity" conducted in 2009 only $25 \%$ of the respondents reported practising physical activity at least once a week [20]. Similar results demonstrating the occasional practising of physical activities by the majority of adult Poles were obtained by $[25,26,16]$. The increased physical activity of the fans probably results from the fact that, by participating in a sports event, the fans are interested in the particular discipline. It is not only a one-of show for them, but also the psychological and personal determinant of their physical activity. According to Spence and Lee [27] there are eight groups of factors that influence whether or not physical activity is undertaken, two of which relate to the person and the remaining to elements of the physical and social environment. The personal determinants of physical activity were seen as the group of psychological and biological variables. The first included mainly the sense of self-efficacy and minimizing barriers as well as recognizing the benefits of physical activity, positive attitudes and satisfaction coming from physical activity [27].

The drivers of above-average physical activity of fans can also be seen in a more positive and modelled attitudes towards physical activity. The participation in international sports events as a fan is connected with positive emotional experiences, feelings which become emotional and motivational component of the general attitude towards sport. Sollerhed et al. [28] brought the conclusion that can also provide us with the answer to the question surrounding the reasons for higher physical activity of fans when compared to those who are not interested in sports events. According to the authors quoted, there is a link between a strong sense of relationships among people and their positive attitude to sport. Participation as a fan in a major international sports event has a huge impact on the formation of strongly positive relationships related to the supporting of the national team, which probably encourages those fans to undertake physical activity. The confirmation of this reasoning is that most respondents declared that they undertake a form of physical activity in line with the sports discipline they support or this watched discipline and other sports. However, it cannot be applied to women who are basketball and football supporters.

The studies presented also showed a significant frequency and volume of physical activity amongst fans who declared that they undertake physical activity on average 3 times per week, with an average total volume of 3.8 hours per week. The volume and frequency of the fans' physical activity, however, is not enough according to most health standards. The recommendations adopted in the United States and Great Britain state that it is necessary to take moderate physical activity for 30-40 minutes, 5-7 days a week [29].

The research conducted showed that female participants of international sports events are less physically active than men. This is not surprising since, in both domestic and foreign studies, women are less active than men [30, 31, 32, 25, 33, 16].

However, a lot of fans declared that they did not practise any physical activity. These declarations are significantly varied depending on the gender and sports discipline they support. It is usually, however, a lower percentage than reported in the Eurobarometr surveys according to which as much as $49 \%$ of Poles refrain from any physical activity [20]. In other studies this figure was $36 \%$ [25] and $37.2 \%$ [14].
Some results obtained by means of descriptive and variance analysis were also confirmed by the correspondence analysis, which proved to be a useful "tool" to determine the statistical characteristics of individual groups of supporters, that is the fans of basketball, volleyball and football who visited international sports events to watch team games. Among the variables describing a particular group of fans (sex, age, place of residence, physical activity), which were taken into consideration in this correspondence analysis, of particular importance to this work was the level of physical activity of respondents; it confirmed the results obtained by other statistics "tools". Young fans of basketball and football who are 19-35 years old are usually physically active. In turn, the people who do not undertake any active physical activity are usually slightly older people compared to the previous group of fans. They are volleyball and football fans at the age of 36-55 years. The age was certainly one of the variables affecting undertaking physical activity by the respondents but it should be remembered that this "picture" was also determined by many other personal and environmental factors [27].

As pointed out in the introduction, the fans participating in international sports events are often tourists so they are consumers of both sports and tourist services (e.g. accommodation, food, transport or tickets) [5]. Having the knowledge of the physical activity level of different groups of fans, the sport-tourism product can be expanded by recreational sports services (physical activity), which can be offered to sports fans as a part of their stay. The characteristics of supporters, including their physical activity, carried out by means of the correspondence analysis, can be helpful in matching potential offer of physical recreation to the needs of a particular segment of guests; the fans of various sports, who are also tourists. As mentioned, in the modern way of life recreational physical activity has an important place in life for many people [16]. In the case of these studies it is relevant especially for the basketball fans, who are more physically active. The wider offers of travel services for fans, with the elements of physical recreation, apart from the passive participation as fans, are not only more attractive when staying at international sports events, but contribute to the wider promotion of sport, including the "sport for all" that is the recreation.

\section{Conclusions}

The research yielded the following conclusions:

1. The majority of fans at international sports events studied were physically active. This applied mostly to the basketball fans. The gender of the respondents significantly differentiated undertaking physical activity in the researched groups.

2. In the research groups analysed the weekly volume of physical activity was significantly differentiated. The basketball fans spent the greatest amount of time on physical activities, while the volleyball fans the lowest. The average frequency of physical activities was the same in all groups. Nearly half of the fans participating in the European volleyball Championships declared a total lack of physical activity.

3. Generally, the characteristics of fans developed by using the correspondence analysis were as follows:

- The football fans were mostly men aged 19-55, mainly from big cities of over 100000 inhabitants. Within this group, the age group 19-35 years, along with the basketball fans, was the most physically active; the age group 36-55 years, along with the volleyball fans, was the most physically inactive.

- The volleyball fans were mostly young people under 
18 years of age, mainly women from small towns up to 100000 inhabitants. Within this group, the age group 36-55 years, along with the football fans, was the most physically inactive. The characteristics of this group proved that young people not only support, but also practice sport. On the other hand, the respondents from the age group 36-55 years mainly support only.

- The basketball fans were mostly from big cities of over 500000 residents or from small towns from 10000 to 50000 residents. The respondents from this group were usually people who practised sport and mainly young people up to 35 years of age.

Further studies of the physical activity of the fans who participate in international sports events should, apart from the level of physical activity, focus on a detailed analysis of the relationship between this level (i.e. active participation in sport) and passive supporting. This would allow, for example, more precise determination of the importance of participation in the international sports events as fans-tourists, which are being organised more and more often in Poland, for undertaking recreation activity by people and the whole of society.

\section{Literature}

1. Klisiński, J. (2005). Sport tourism as academical discipline and component of sport management. In H. Mruk (Ed.), Marketing about sport. Poznań: Sport \& Business Foundation (pp. 11-26). [in Polish]

2. Krawczyk, Z. (2006). Present trends in tourism development. In J. Kosiewicz \& K. Obodyński (Eds.), Tourism and recreation. Theoretical and practical dimensions. Rzeszów: Uniwersytet Rzeszowski (pp. 33-45). [in Polish]

3. Zauhar, J. (2004). Historical Perspectives of Sports Tourism. Journal of Sport Tourism 9(1), 5-10.

4. Hall, C.M. (1992). Adventure, sport and health. In C.M. Hall \& B. Weiler (Eds.), Special interest tourism. London: Belhaven Press (pp. 141-158).

5. Standeven, J. \& Deknop P. (1999). Sport Tourism. Champaign: Human Kinetics.

6. Winiarski, R.W. \& Zdebski J. (2008). Psychology of tourism. Warszawa: Wydawnictwo Akademickie i Profesjonalne. [in Polish]

7. Robinson, T. \& Gammon S. (2004). A Question of Primary and Secondary Motives: Revisiting and Applying the Sport Tourism Framework. Journal of Sport Tourism 9(3), 221-233.

8. Getz, D. (2008). Event tourism: definition, evolution and research. Tourism Management 29(3), 403-428.

9. Lenartowicz, M. (2001). A new area of research - sports tourism. Kultura fizyczna 1-2. [in Polish]

10. Bouchard, C. \& Shephard R. J. (1994). Physical activity, fitness, and health: The model and key concepts. In C. Bouchard, R. J. Shephard \& T. Stephens (Eds.), Physical activity, fitness, and health. Champaign: Human Kinetics (pp. 77-88).

11. Corbin, C. B., Corbin W. R., Welk K. A. \& Welk G. J. (2007). Fitness and wellness. Form, fitness, health. Poznań: Zysk i S-ka. [in Polish]

12. Mynarski, W., Garbaciak W., Stokłosa H. \& Grzadziel G. (2007). Physical fitness focused on health (H-RF) in Upper Silesia. Katowice: AWF. [in Polish]

13. Biddle, S. J. H., Soós I., Hamar P., Sandor I., Simonek J. \& Karsai I. (2009). Physical activity and sedentary behaviours in youth: Data from three Central-Eastern European countries. European Journal of Sport Science 9(5), 295-301.
14. Drygas, W., Bielecki W. \& Puška P. (2002). The opinion of citizens of six European countries on Physical activity. Project „Bridging East - West Health Onlooker”. Medycyna Sportowa 18(5), 169-174. [in Polish]

15. Martinez-Gonzalez, M., Martinez J.A., Hu F.B., Gibney M.J. \& Kearney J. (1999). Physical inactivity, sedentary lifestyle and obesity in the European Union. International Journal of Obesity 23, 1192-1201.

16. Mogiła-Lisowska, J. (2010). Recreational physical activity of adult Poles - conditions and style of participation. Warszawa: AWF. [in Polish]

17. Ruetten, A., Ziemainz H., Schena F, Stahl T., Stiggelbout M, Vanden Auweele Y. et al. (2003). Using different physical activity measurements in eight European countries. Results of the European Physical Activity Surveillance System (EUPASS) time series survey. Public Health Nutrition 6(4), 371-376.

18. Rütten, A. \& Abu-Omar K. (2004). Prevalence of physical activity in the European Union. Soz.- Präventivmedizn 49, 281-289.

19. Sjöström, M., Oja P., Hagströmer M., Smith B. J. \& Bauman A. (2006). Health-enhancing physical activity across European Union countries: the Eurobarometer study. Journal of Public Health 14(5), 291-300.

20. Sport and Physical Activity. Special Eurobarometr 72.3. (2010). Brussels: European Commission.

21. Suchomel, A., Sigmundowa D. \& Frömel K. (2008). The Role of physical activity in the lifestyle of inhabitants of the Liberec Region. Human Movement 19-26.

22. Poles' Participation in sport and physical recreation in 2008. Information and Statistical Papers. (2009). Warszawa: GUS. [in Polish]

23. Benzecri, J. P. (1992). Correspondence Analysis Handbook. New York: Marcel Dekker.

24. Greenacre, M. \& Hastie T. (1987). The Geometric Interpretation of Correspondence Analysis. Journal of the American Statistical Association 82 (398), 437-447.

25. Drygas, W., Kwaśniewska M., Kaleta D., Pikala M., Bielecki W., Głuszek J. et al. (2009). Epidemiology of physical inactivity in Poland: Prevalence and determinants in a former communist country in socioeconomic transition. Public Health 123, 592-597.

26. Kaleta, D. \& Jegier A. (2005). Characteristics of physical activity of urban adult population in Poland on the example Lodz. Przegląd Lekarski 62 (suppl 3), 14-17. [in Polish]

27. Spence, J. C. \& Lee R. E. (2003). Toward a comprehensive model of physical activity. Psychology of Sport and Exercise 4, 7-24.

28. Sollerhed, A., Ejlertsson G. \& Apitzsch, E. (2005). Predictors of strong sense of coherence and positive attitudes to physical education in adolescents. Scandinavian Journal of Public Health 33, 334-342.

29. MacAuley, D. (2001). The potential benefits of physical activity undertaken by elderly people. Medicina Sportiva 5(4), 229-236. [in Polish]

30. Allison, K. R., Dwyer M., Goldenberg E., Fein A., Yoshida K. \& Boutilier M. (2005). Male adolescents' reasons for participating in physical activity, barriers to participation, and suggestions for increasing participation. Adolescence 40(157), 155-170.

31. Baker, E. A., Bennan L. K., Brownson R. \& Houseman R. A. (2000). Measuring the determinants of physical activity in the community: Current and future directions. Research Quarterly for Exercise and Sport 71(2), 146-158. 
32. Ball, K. (2006). People, places... and other people? Integrating understanding of intrapersonal, social and environmental determinants of physical activity. Journal of Science and Medicine in Sport 9, 367-370.

33. McNeill, H. L., Kreuter M. W. \& Subramanian S.V. (2006). Social environment and physical activity: A review of concepts and evidence. Social Science \& Medicine 63, 10111022.

Submitted: August 16, 2012

Accepted: September 26, 2012 